\title{
Surfaces
}

\section{INTRODUCTION. FIRST CONFERENCE OF THE ICHU, APRIL 1994}

\section{Volume 4, 1994}

CONFÉRENCE INTERNATIONALE SUR LE DISCOURS HUMANISTE (PREMIÈRE RENCONTRE, 3-8 AVRIL, 1994)

INTERNATIONAL CONFERENCE ON HUMANISTIC DISCOURSE (FIRST MEETING, APRIL 3-8, 1994)

URI : https://id.erudit.org/iderudit/1064965ar

DOI : https://doi.org/10.7202/1064965ar

Aller au sommaire du numéro

\section{Éditeur(s)}

Les Presses de l’Université de Montréal

\section{ISSN}

1188-2492 (imprimé)

1200-5320 (numérique)

Découvrir la revue

Citer ce document

(1994). INTRODUCTION. FIRST CONFERENCE OF THE ICHU, APRIL 1994.

Surfaces, 4. https://doi.org/10.7202/1064965ar
Résumé de l'article

Ce document décrit le contexte pratique et théorique dans lequel ont été rédigés les essais (numérotés ici de 302 à 310) distribués à tous les participants de la première rencontre de l'« International Conference for Humanistic Discourse ".
Tous droits réservés @ Surfaces, 1994

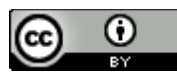

Ce document est protégé par la loi sur le droit d'auteur. L’utilisation des services d'Érudit (y compris la reproduction) est assujettie à sa politique d'utilisation que vous pouvez consulter en ligne.

https://apropos.erudit.org/fr/usagers/politique-dutilisation/ 


\title{
INTRODUCTION
}

FIRST CONFERENCE OF THE ICHU, APRIL 1994

International Conference for Humanistic Discourses

\begin{abstract}
This document describes the theoretical and practical context for the essays (published as 302-310) that were distributed to participants of the first meeting of the International Conference for Humanistic Discourse.
\end{abstract}

\section{RÉSUMÉ}

Ce document décrit le contexte pratique et théorique dans lequel ont été rédigés les essais (numérotés ici de 302 à 310) distribués à tous les participants de la première rencontre de l'<<International Conference for Humanistic Discourse >>.

\section{Introduction}


The articles Surfaces publishes in this section of its fourth volume constitute the record of a series of colloquia whose purpose is described in the two preliminary documents that follow. The first meeting of the International Conference for Humanistic Discourses was held at the University of California, Irvine, from April 3-8, 1994. It was sponsored by the Transcoop Program of the Alexander von Humboldt Foundation and the School of Humanities and the Graduate Division of UCI. At the center of the meeting were eight papers written and distributed in advance, with one session devoted to each. These were not to be finished essays so much as preliminary drafts or working papers intended to stimulate discussion -- and they did.

The papers, found as files 302-310 of the present volume, are followed by edited transcriptions of the discussions prompted by them. Herein are reprinted relevant sections of the memoranda that defined the conference and assigned the papers.

\section{Initial Definition and Planning Memo (October 1992)}

A core group of Western and East Asian scholars are planning the creation of an International Conference for Humanistic Discourses, a conference concerned with bridge-building between Western and East Asian cultures, and primarily devoted to the comparative study of the discourses of the humanities as they play their role in constituting each of the cultures. Funding from the Alexander von Humboldt Foundation in Germany and the University of California, Irvine, will support annual meetings for three years. Our first meeting will be held in April 1994 at UCI. There will be a second meeting at Irvine in March-April 1995 and a third in Munich in September 1996. The three workshops are meant to intensify the scholarly cooperation between the United States and Germany as scholars from these countries interact with those of East Asia.

Co-Principal Investigators for the initial three-year project are Wolfgang Iser and Murray Krieger. The other members of the Core Group are Hazard Adams, Ernst Behler, Hendrick Birus, Jacques Derrida, J. Hillis Miller, Ludwig Pfeiffer, Bill Readings, Ching-hsien Wang, and Pauline Yu. All core group members will participate in each of the three conferences, with additional East Asian scholars participating in the second and third.

The over-all subject for the three conferences will be "Culture and Cultures: and the Spaces Between." (We mean both the spaces between the variety of 
discourses within a culture and the spaces between cultures, U.S., European, and East Asian.) Which are the texts that mark the boundaries among this variety -- or are there only boundary texts? Many of us are concerned with observingacross cultures, as well as within each of them, the relations -- whether of distinctions or overlappings -- between the discourses of the arts (especially, but not exclusively, the literary arts) and other cultural discourses.

Subject of the first meeting: the defining limits, distinctions, and overlappings within and among humanistic discourses in the United States, Germany, and France.

1. The function, media, and interpretive institutions of humanistic discourses. The "humanistic" put in question; how to determine whether to speak of "discourse" or "discourses"? From literature and the arts (what we may term "the discourses of the arts") to philosophy, history, etc., can we claim that we find -- or constitute -- a spectrum?

2. The role of the "literary" (also to be put in question) within the discourses? The relation of "literary language" (or at least the "literary" reading of language) to "language" (or at least the other-than-literary reading of language)? Is there a distinctive reading method stimulated by the literary medium? by the media of all discourse? If there are functions that are peculiarly humanistic, do the discourses of the arts provide a distinctive humanistic function?

\section{Follow-up Memorandum (July 1993)}

In our earlier statement we blurred terms like "culture" and "discourse." This blurring was evidence of our need, in providing some preliminary guidance for our first meeting, to clarify our attitudes toward the two terms, our assumptions about them, our definitions of them, and our sense of how they function and how they interrelate. With this in mind, we submit a number of miscellaneous and at times overlapping questions that are intended to stimulate your thinking. We ask that you ponder and address any one or several of them in writing your first brief papers that will furnish the basis of our discussions.

1. Is it the task of "humanistic discourse(s)" to intervene in culture or only to look back and observe? 
2. Whose discourse is "cultural discourse" -- is it academic or "popular" or that of different political interest groups? Why do the latter, even when opposing existing culture, continue to use institutions as they are? The term "academic" to be put in question; and of course the term "culture" to be put in question.

3. Is "marginal" cultural discourse only what is being claimed by those on the political margin? Is academic "humanistic discourse(s)" not marginal? If it is, what, then, does it achieve?

4. Is humanistic discourse(s) a necessary ingredient of "culture"? Ask this question, more narrowly, about the discourses of the arts. How do the two (humanistic discourse(s) and discourses of the arts) interrelate? If they are necessary ingredients of culture, do they represent different kinds of necessities? Is one prior to (or even an ingredient of) the other? Or are they distinct? This is meant to return us to our central question: To what extent are the arts still (if they ever were) indispensable for the constitution of what we call "culture"? For the constitution of humanistic discourse?

5. Is "elitist" discourse necessary for cultural differentiation? To expand: Does the academic humanist have the right to assign himself or herself the cultural task of definition, and to attribute value (or lack of value) to the various entities being defined. Or has humanistic discourse become culturally obsolete? Can one avoid calling this discourse "elitist," and, if not, what governs the differentiations among discourses? If differentiations are permitted to collapse, is there still "culture" (or is culture defined by its differentiations?)?

6. How, then, would we define the "arrogance" behind those who would insist on the authority of humanistic discourse? How would we define the arrogance behind those who would deny them the right to so insist? Can we frame any of these questions without some assumption of "disinterest" in addressing them? How, in view of recent arguments, can we persist in this assumption? On what grounds? Pragmatic grounds? How so?

7. Do we want to give away "culture" to those redefining it today? Do we want to distinguish it from "civilization"? What is the political price to be paid for the humanist's version of "culture"? What right do we have (if any) to invest "culture" with value-ridden criteria? Who, then, is to define what culture is or whose culture deserves that name? It is too cheap -- and it's tautological -- merely to say "those with the power to do so." 
8. Perhaps many of the above questions would be precluded if we turn from concerns about defining culture and discourse to attempts to treat them functionally only. Hence, for example, instead of asking, "What is culture?" we can ask, "Why is culture?"

9. We must, jointly, consider all these questions from the standpoint of Germany, the United States, and France. What differences can we discern among these, both historically and in terms of our present cultures, academic and extra-academic?

In view of question 9 , above, it follows that only those of our members who are primarily scholars of Western cultures should be responsible for writing the brief position statements for our first meeting. We hope that our two members who represent East Asian cultures, will -- without writing papers at this time -- fully participate in that meeting and will carry away ideas that will make them ideal transmitting agents and leaders of our second meeting in 1995.

May 26, 1994

Surface Page d'Acceuil/Home Page 